\title{
PENINGKATAN PENGETAHUAN TENTANG MEKANISME KOPING ADAPTIF, KESEHATAN TIDUR DAN KESEHATAN GIGI DAN MULUT ANAK SEKOLAH
}

\author{
Eka Wahyuningrum ${ }^{1)}$, Natalia Ratna Yulianti²), Andri Kenti Gayatina ${ }^{3)}$, \\ Christin Wibhowo ${ }^{4}$ \\ ${ }^{1}$ Proram Studi S1 Ilmu Keperawatan, STIKes St. Elisabeth Semarang \\ 2,3 Proram Studi Profesi Ners, STIKes St. Elisabeth Semarang \\ E-mail korespondensi: Ekawahyu877@gmail.com
}

\begin{abstract}
Background: Preliminary studies found variations in sleep habits, coping mechanism and cavities and dirty teeth on school-age children. Resolving health problems that occur in children requires a family center care approach. Objective: Increasing parental knowledge about sleep health and adaptive coping mechanism of children and increasing children's knowledge about oral health. Method: This activity is carried out for 3 days. The first day and third day counseling about sleep health and dental and oral health for children through snakes and ladder's game and video of tooth brush and sleep. Activity on second day was counseling to all parents of school children about adaptive coping mechanism and children's sleep health. Based on observations on these activities, several positive impacts were found including; 1) Children and parents were involved in activities, all children were involved and more than 50\% of parents participated in the activity, 2)The child looks enthusastic of the games and videos that were shown, parents looked enthusiastic asking during the counseling. Results: There were significant increasing knowledge in children about oral health and significant increasing knowledge in parents immediately after counseling and decreasing knowledge after 3 months posttest. Conclusion: Counseling to parents and children were increasing knowledge soon after counseling.
\end{abstract}

Keywords : Anak Sekolah; Sleep Hygiene; Kesehatan Tidur; Mekanisme Koping; Kesehatan Gigi Mulut

\section{PENDAHULUAN}

Anak usia sekolah berada pada tahap pertumbuhan dan perkembangan. Perawatan kesehatan yang tepat oleh anak didukung oleh orangtua sangat dibutuhkan demi optimalnya pertumbuhan dan perkembangan anak.
Studi pemetaan tentang gambaran respon anak terhadap frustasi didapatkan orangtua menyatakan: anak mudah menjadi frustasi jika keinginannya tidak terpenuhi adalah kadangkadang $(39,2 \%)$ dan selalu (5,9\%). Orangtua menyatakan anak mudah menangis adalah kadang-kadang $(60,8 \%)$ dan selalu $(13,7 \%)$. 
terlihat marah tanpa sebab yang jelas adalah kadang-kadang (33,3\%) dan selalu (3,9\%). Anak terlihat menghindar dari teman-teman atau anggota keluarganya adalah kadangkadang (11,8\%), anak terlihat berperilaku merusak dan menentang terhadap lingkungan sekitarnya adalah kadang-kadang (11,8\%).

Orangtua menyatakan anak memperlihatkan adanya perasaan ketakutan atau kecemasan berlebihan yang tidak dapat dijelaskan asalnya dan tidak sebanding dengan anak lain seusianya adalah kadangkadang (9,8\%) dan selalu (2\%), anak menunjukkan perilaku kebingungan sehingga mengalami kesulitan dalam berkomunikasi dan membuat keputusan adalah kadangkadang (13,7\%) dan selalu (2\%). Anak sering sekali mengeluh sakit kepala, sakit perut, atau keluhan - keluhan fisik lainnya adalah kadang-kadang $(43,1 \%)$ dan selalu $(3,9 \%)$. Orangtua menyatakan anak sering sekali mengeluh putus asa atau berkeinginan untuk mengakhiri hidupnya adalah kadang-kadang $(2 \%)$ dan selalu (2\%). Orangtua menyatakan anak menunjukkan adanya kemunduran perilaku adalah kadang-kadang (5,9\%) dan selalu (3,9\%), anak melakukan perbuatan berulang-ulang tanpa alasan yang jelas adalah kadang-kadang (21,6\%) dan selalu (2\%). Kuesioner tidak terisi hanya ditemukan pada pernyataan anak mudah menjadi frustasi jika keinginannya tidak terpenuhi sebanyak 1 $(2 \%)$.

Gambaran tidur pada anak didapatkan data orangtua menyatakan anak biasanya bangun pada pukul 05.00-06.00 WIB (62,7\%). Menurut orangtua, anak bangun terlalu siang adalah kadang-kadang (49\%). Orangtua menyatakan anak biasa tidur malam mulai pukul 20.00-21.00 WIB (66,7\%) dan lebih dari pukul 21.00 WIB (19,6\%). Orangtua menyatakan anak tidur menggunakan boneka adalah tidak pernah (51\%) dan kadangkadang (29,4\%). Orangtua menyatakan durasi anak tidur malam adalah 8 jam (60,8\%). Orangtua mengatakan anak mengompol saat malam hari adalah kadang-kadang (11,8\%), anak selalu tidur pada jam yang sama setiap hari adalah kadang-kadang (51\%) dan tidak pernah $(11,8 \%)$. Orangtua menyatakan anak malas bangun tidur adalah kadang-kadang $(68,6 \%)$ dan anak tidur siang adalah kadangkadang $(56,9 \%)$. Orangtua menyatakan guru menyampaikan anak terlihat mengantuk di kelas adalah kadang-kadang (11,8\%), anak mengompol di kelas adalah kadang-kadang (2\%). Orangtua mendapati anak mengompol siang hari dalam seminggu terakhir adalah kadang-kadang (2\%) dan selalu (2\%). (Wahyuningrum, Yulianti and Gayatina, 2019) 


\section{GEMASSIKA: Jurnal Pengabdian Kepada Masyarakat}

Vol. 4 No. 2 November 2020

Pemeriksaan fisik yang dilakukan juga menunjukkan hasil pemeriksaan antopometri rata-rata berat badan (32,94 vs 28,71), tinggi badan (131, 94 vs 129,79), IMT (32,94 vs $28,71)$ dan lingkar lengan atas $(20,72$ vs 19,02) didapatkan anak laki-laki lebih besar daripada anak perempuan. Hasil pemeriksaan fisik menunjukkan adanya masalah kesehatan mata (ketajaman penglihatan $(88,1 \%)$ ), masalah kesehatan gigi dan mulut (gigi kotor (72,9\%); gigi berlubang (62,7\%); tonsil membesar (16,9\%); masalah kebersihan diri (kuku kotor $(50,8 \%))$ serta cedera (ada bekas luka (39\%)). (Wahyuningrum, Gayatina and Yulianti, 2020)

Berdasarkan uraian diatas menunjukkan anak mengalami kebutuhan kesehatan tidur, kesehatan gigi dan mulut yang belum terpenuhi. Sehingga sebagai institusi pendidikan tinggi yang bertanggung jawab melakukan tri dharma perguruan tinggi, maka kami berinisiatif untuk melakukan peningkatan kesehatan mental emosional, kesehatan tidur, kesehatan gigi dan mulut yang didahului dengan upaya peningkatan pengetahuan pada anak dan orangtua.

\section{MASALAH, TARGET DAN LUARAN}

Masalah yang dialami oleh anak sekolah berdasarkan studi pendahuluan adalah anak mengalami permasalahan dalam kebutuhan tidur, permasalahan pada gigi dan mulut dan permasalahan pada mekanisme koping. $68,6 \%$ orangtua menyatakan kadang-kadang anak malas bangun tidur, $62,7 \%$ anak mengalami gigi berlubang dan $33,3 \%$ orangtua mengatakan kadang-kadang anak terlihat marah tanpa sebab yang jelas. Tindakan awal yang dapatdilakukan untukmengatasi masalah kesehatan anak ini perlu melibatkan orangtua dan anak dengan meningkatkan pengetahuan anak dan orangtua. Target pada kegiatan ini adalah kehadiran anak dan orangtua lebih dari 50\% jumlah seluruh anggota mitra. Luaran dari kegiatan ini adalah bagi orangtua, peningkatan pengetahuan orangtua tentang kesehatan tidur dan mekanisme koping anak dan bagi anak, peningkatan pengetahuan anak tentang kesehatan gigi dan mulut dan kesehatan tidur. Peningkatan pengetahuan orangtua dan anak itu diharapkan mampu memberikan pedoman bagi sikap orangtua dan anak dalam meningkatkan mekanisme koping adaptif, kesehatan tidur, gigi dan mulut pada anak sekolah.

\section{METODE PELAKSANAAN}

Metodeyang digunakan dalampengabdian masyarakat ini dengan melakukan penyuluhan kepada orangtua dan anak dan disertai dengan pretest posttest without control group untuk mengevaluasi pengetahuan orangtua. 
Kegiatan pengabdian masyarakat ini diawali dengan rapat persiapan tim keperawatan Anak STIKes St Elisabeth Semarang, Pembuatan RAB (Rancangan Anggaran Belanja), jadwal kegiatan dan surat menyurat dengan Mitra dan Dinas Penididkan Kota Semarang. Kegiatan ini sudah mendapat ijin dari dinas pendidikan kota Semarang dan Kepala Sekolah Dasar Kristen Imanuel.

Pengabdian masyarakat untuk meningkatkan pengetahuan tentang mekanisme koping adaptif dan kesehatan tidur anak sekolah pada orangtua dilakukan dengan penyuluhan kesehatan secara langsung kepada orangtua dan melibatkan pakar parenting dan kesehatan tidur. Pengabdian masyarakat untuk meningkatkan pengetahuan tentang kesehatan tidur anak dilakukan dengan menggunakan video, sedangkan untuk meningkatkan pengetahuan anak tentang kesehatan gigi dan mulut dilakukan dengan metode bermain ulartangga dan menonton video.

Kegiatan dilakukan dalam tiga hari. Pada hari pertama dan ketiga diawali dengan doa, perkenalan, menyanyi bersama, pembagian kelompok, bermain ulartangga secara berkelompok dan melihat video bersama, pada hari yang kedua diawali dengan doa, sambutan, penyuluhan peningkatan mekanisme koping adaptif oleh Psikolog dan diskusi, penyuluhan kesehatan tidur pada anak oleh Dosen keperawatan anak dengan kepakaran kesehatan tidur.

\section{HASIL PEMBAHASAN}

Kegiatan ini dilakukan di SD Kristen Imanuel dengan melibatkan 61 anak sekolah dan orangtua. Kegiatan dilaksanakan pada hari Senin sampai dengan Rabu, 15-17 Juni 2019. Hari pertama dilakukan penyuluhan tentang kesehatan tidur dan kesehatan gigi dan mulut kepada anak kelas 1-3 SD. Hari ketiga dilakukan penyuluhan tentang kesehatan tidur dan kesehatan gigi dan mulut kepada anak kelas 4-6 SD. Hari pertama dan ketiga dipimpin oleh tim keperawatan anak STIKes St. Elisabeth Semarang yang dibantu oleh sebelas mahasiswa yang sudah dilatih. Penyuluhan tentang kesehatan gigi dan mulut melalui permainan ular tangga dan video sedangkan penyuluhan tentang kesehatan tidur menggunakan media video.

Kegiatan pengumpulan data dan pengabdian masyarakat pada anak dilakukan pada anak kelas 4-6 SD, dengan rincian sebagai berikut:

1. Pengisian pretest tentang kesehatan gigi dan mulut oleh anak SD kelas 4-6 SD.

2. Bermain dengan anak bertema "Gigiku bersih, sehat dan kuat" melalui permainan ular tangga" 


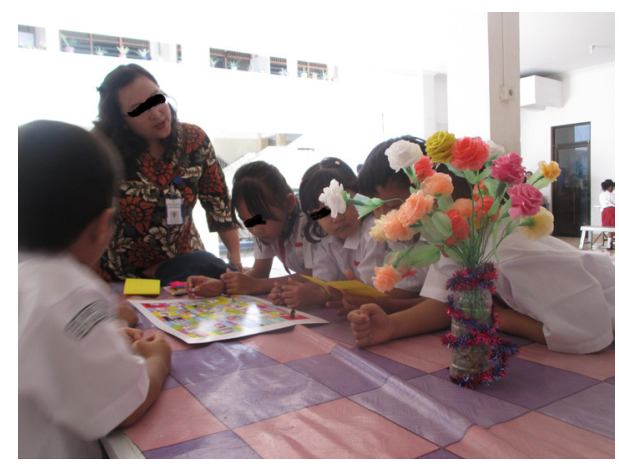

Gambar 1

3. Menonton bersama video tentang sleep hygiene dan cara menggosok gigi yang benar. Kegiatan ini dilakukan pada anak sekolah

4. Pengisian posttest tentang kesehatan gigi dan mulut oleh anak SD kelas 4-6 SD.

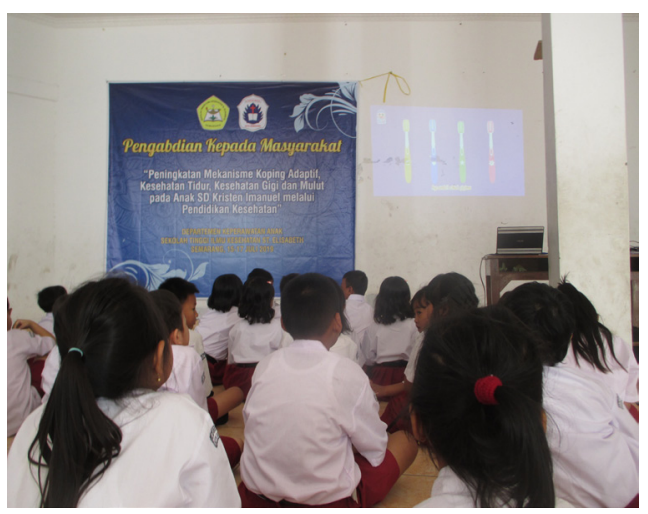

Gambar 2

Kegiatan pada hari kedua berupa penyuluhan kepada semua orangtua anak sekolah tentang mekanisme koping adaptif dan kesehatan tidur anak. Pada hari kedua ini melibatkan dosen Psikologi UNIKA dengan kepakaran parenting dan salah satu dosen tim keperawatan anak dengan kepakaran kesehatan tidur anak.
Kegiatan pengumpulan data dan pengabdian masyarakat pada orangtua sebagai berikut:

1. Pengidentifikasian masalah koping dan kesehatan tidur dengan kuesioner tentang pengetahuan koping adaptif dan kesehata tidur yang diisi orangtua.

2. Penyuluhan tentang "Peningkatan respon koping yang adaptif anak sekolah dengan bimbingan orangtua" oleh Psikolog klinik pada orangtua dan guru sekolah.

3. Penyuluhan tentang kesehatan tidur anak oleh Dosen keperawatan anak pada orangtua dan guru.

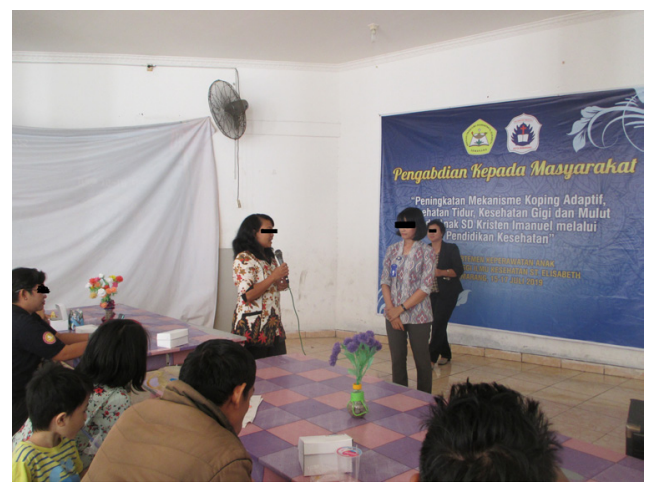

\section{Gambar 3}

4. Pengukuran kembali pengetahuan masalah koping dan kesehatan tidur dengan kuesioner yang di isi peserta.

5. Setelah 3 bulan, dilakukan pengukuran kembali pengetahuan masalah koping dan kesehatan tidur dengan kuesioner yang di isi peserta. 
Selama kegiatan pengabdian dilakukan observasi dan evaluasi. Observasi yang dilakukan meliputi, keterlibatan anak dan orangtua dan antusias terhadap kegiatan. Evaluasi berupa pengisian kuesioner yang dilakukan dua kali yaitu persis setelah kegiatan dan 3 bulan setelah kegiatan.

\section{Observasi}

1. Keterlibatan anak dan orangtua

Semua anak dilibatkan dalam kegiatan ini. Kelompok anak yang kelas 1-3 SD (46 siswa) maupun kelas 4-6 SD (29 siswa), 100\% hadir dalam kegiatan ini. Anak terlibat dari awal kegiatan sampai dengan akhir. Tidak ada anak yang ijin untuk kegiatan lain.

Sebagian besar orangtua hadir, lebih dari $50 \%$ orangtua hadir dalam kegiatan. Beberapa orangtua datang terlambat dan ada beberapa orangtua yang pulang lebih awal karena kegiatan lain. Hal ini membuat beberapa orangtua tidak dapat dinilai pengetahuannya (karena kuesioner tidak diisi) pada pretest maupun posttest. Walaupun demikian, semua materi tetap diberikan seluruhnya.

2. Antusiasme dalam kegiatan

Anak yang mengikuti kegiatan baik pada kelompok 1-3 SD maupun 4-6 SD terlihat antusias. Semua mengikuti kegiatan bermain ulartangga dengan senang. Jumlah anak dalam kelompok bermain 5 sampai dengan 8 anak, sehingga fasilitator dapat mengendalikan anak dalam kegiatan bermain dengan lebih baik.

Anak terlihat antusias saat mendapat giliran membuang dadu dan membaca undian. Pada awal kegiatan bermain yang terbagi dalam kelompok, anak-anak terlihat malu, namun setelah beberapa saat anak mulai dapat berinteraksi dengan teman 1 kelompoknya dengan baik. Anak dapat mengenal teman satu kelompoknya yang pada awalnya tidak dikenalnya.

Orangtua juga terlihat antusias pada saat pemberian penyuluhan tentang kesehatan mental maupun kesehatan tidur. Salah satu bentuk antusias orangtua dengan banyaknya orangtua yang bertanya pada saat sesi tanya jawab. Lebih dari 3 orangtua bertanya pada masing-masing penyuluh. Bahkan pada akhir kegiatan penyuluhan ada salah satu orangtua yang meminta waktu menyampaikan harapannya. Harapan orangtua tersebut supaya kegiatan penyuluhan seperti ini sering dilaksanakan sehingga mereka dapat mengasuh anak mereka dengan tepat. 


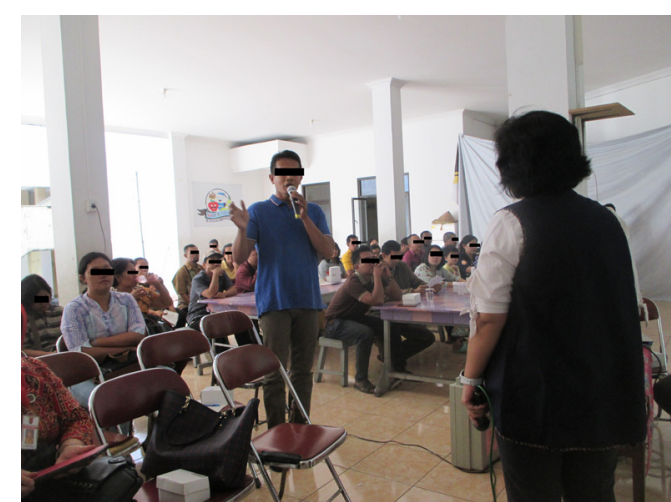

Gambar 4

\section{Evaluasi}

Evaluasi terhadap pengetahuan anak dan orangtua dilakukan dengan menilai pengetahuan orangtua terhadap kesehatan tidur dan mekanisme koping adaptif serta pengetahuan anak tentang kesehatan mulut dan gigi.
1. Pengetahuan orangtua terhadap kesehatan tidur dan kesehatan mental.

Pengetahuan orangtua dinilai berdasarkan kuesioner yang terkumpul. Kuesioner yang terkumpul untuk pretest sebanyak 51 kuesioner, untuk posttest yang dilaksanakan segera sesudah penyuluhan sebanyak 27 dan untuk posttest yang dilaksanakan 3 bulan setelah tindakan sebanyak 38 kuesioner. Kuesioner yang tidak diisi diberi skor 0 . Pada pengolahan data didapatkan data tidak berdistribusi normal. Sehingga untuk pengolahan data menggunakan uji nonparametric kruskalwallis test. Gambaran pengetahuan orangtua sebelum, sesudah dan sesudah 3 bulan ditunjukkan dalam tabel dibawah ini:

Tabel 1. Perbedaan rerata pengetahuan orangtua tentang kesehatan tidur dan kesehatan mental anak sekolah

\begin{tabular}{|c|c|c|c|c|c|c|c|}
\hline & \multicolumn{2}{|c|}{ Sebelum } & \multicolumn{2}{|c|}{ Segera Sesudah } & \multicolumn{2}{|c|}{ Sesudah 3 bulan } & \multirow[t]{2}{*}{$p$} \\
\hline & $\begin{array}{c}\text { Mean } \\
\text { (SD) }\end{array}$ & $\begin{array}{c}\text { Median } \\
\text { (minimum } \\
\text {-maximum) }\end{array}$ & $\begin{array}{c}\text { Mean } \\
(\mathrm{SD})\end{array}$ & $\begin{array}{l}\text { Median } \\
\text { (minimum- } \\
\text { maximum) }\end{array}$ & $\begin{array}{c}\text { Mean } \\
\text { (SD) }\end{array}$ & $\begin{array}{c}\text { Median } \\
\text { (minimum- } \\
\text { maximum) }\end{array}$ & \\
\hline $\begin{array}{l}\text { Pengetahuan } \\
\text { tentang kesehatan } \\
\text { tidur pada anak } \\
\text { sekolah }\end{array}$ & $\begin{array}{c}61,86 \\
(18,60)\end{array}$ & $\begin{array}{c}65 \\
(0-90)\end{array}$ & $\begin{array}{c}81,67 \\
(11,51)\end{array}$ & $\begin{array}{c}85 \\
(40-100)\end{array}$ & $\begin{array}{c}59,34 \\
(27,93)\end{array}$ & $\begin{array}{c}70 \\
(0-90)\end{array}$ & $<0,001$ \\
\hline $\begin{array}{l}\text { Pengetahuan } \\
\text { tentang kesehatan } \\
\text { mental pada anak } \\
\text { sekolah }\end{array}$ & $\begin{array}{c}63,33 \\
(27,12)\end{array}$ & $\begin{array}{c}70 \\
(0-100)\end{array}$ & $\begin{array}{c}84,44 \\
(18,04)\end{array}$ & $\begin{array}{c}90 \\
(30-100)\end{array}$ & $\begin{array}{c}66,71 \\
(28,67)\end{array}$ & $\begin{array}{c}70 \\
(0-100)\end{array}$ & $<0,001$ \\
\hline
\end{tabular}

Hasil uji Kruskal-Wallis

114 Peningkatan Pengetahuan tentang Mekanisme... 
2. Pengetahuan anak tentang kesehatan jumlah siswa kelas 4-6 SD. Pengolahan mulut dan gigi

Pengetahuan anak dinilai berdasarkan kuesioner yang telah diisi oleh siswa kelas 4-6 SD. Kuesioner yang terkumpul untuk pretest dan posttest sebanyak 29 sesuai data menggunakan uji nonparametric wilcoxon test. Gambaran pengetahuan anak sebelum dan sesudah bermain ular tangga dan menonton video tentang sikat gigi ditunjukkan dalam tabel dibawah ini:

Tabel 2. Perbedaan rerata pengetahuan anak tentang kesehatan gigi mulut setelah kegiatan bermain ular tangga

\begin{tabular}{lllccc}
\hline & & \multicolumn{3}{c}{ Sebelum } & $p$ \\
\cline { 3 - 4 } & & n & $\begin{array}{c}\text { Mean } \\
(\text { SD) }\end{array}$ & $\begin{array}{c}\text { Median } \\
\text { (minimum - maximum) }\end{array}$ & \\
\hline $\begin{array}{l}\text { pengetahuan anak sebelum kegiatan } \\
\text { bermain dan menonton video }\end{array}$ & 29 & 78,79 & $85(5-95)$ & 0.005 \\
\hline $\begin{array}{l}\text { pengetahuan anak sesudah kegiatan } \\
\text { bermain dan menonton video }\end{array}$ & 29 & 85,86 & $90(55-100)$ & \\
\hline
\end{tabular}

Hasil Uji Wilcoxon

Koping pada anak terhadap stress dapat berupa menjadi frustasi jika keinginan tidak terpenuhi, mudah menangis, mudah marah sampai perilaku merusak. Permasalahan koping pada anak usia prasekolah dikenal dengan temper tantrum merupakan masalah perilaku yang sering terjadi. Dalam penatalaksanaannya orangtua sangat diperlukan partisipasinya dalam memanajemen perilaku ini. Sebagai contoh mencegah trigger yang menstimulasi tindakan temper tantrum anak. (Daniels et al., 2012)

Masalah perilaku tidak hanya terjadi pada masa prasekolah, namun dapat berlanjut pada masa sekolah yang berupa perilaku agresif, hiperaktifitas dan cemas. Luangrath (2011) merekomendasikan manajemen perilaku yang dapat dilakukan adalah menentukan tujuan bersama dengan keluarga, membuat kartu hadiah untuk perilaku yang positif. Hal ini semakin menunjukkan perlunya peran keluarga mengatasi masalah perilaku pada anak.(Luangrath, 2011)

Kesehatan tidur pada anak yang tidak optimal akan mengakibatkan berbagai masalah kognitif dan perilaku Semakin tinggi masalah tidur yang dialami anak berhubungan dengan semakin tingginya masalah kognitif pada anak. Masalah tidur juga berhubungan dengan masalah perilaku internal dan eksternal 


\section{GEMASSIKA: Jurnal Pengabdian Kepada Masyarakat \\ Vol. 4 No. 2 November 2020}

anak (Astill et al., 2012). Masalah tidur terbukti berhubungan juga dengan masalah kecemasan pada anak. Orangtua anak sekolah melaporkan adanya masalah kecemasan pada anak-anak yang mengalami masalah tidur (Fletcher et al., 2016). Anak dengan masalah tidur juga berhubungan perilaku penolakan anak untuk sekolah (Hochadel et al., 2013).

Partisipasi dari orangtua dan sekolah sangat dibutuhkan untuk mengatasi masalah tidur anak usia sekolah. Sleep hygiene dengan pendekatan family center care merupakan salah satu upaya yang bisa dilakukan untuk mengatasi masalah ini. Halal dkk (2014) menyatakan sleep hygiene merupakan salah satu metode yang mudah untuk diterapkan dalam upaya mengatasi masalah tidur pada anak. Pendidikan kesehatan tentang sleep hygiene pada orangtua terbukti menurunkan masalah tidur pada anak (Wahyuningrum, Rahmat and Hartini, 2018). Pendekatan melalui sekolah juga terbukti mengatasi masalah tidur pada anak usia sekolah (Gruber et al., 2016).

Kesehatan gigi mulut pada anak merupakan masalah yang sering terjadi pada anak sekolah. Konsumsi soft drink, oral hygiene, perawatan gigi dan pengalaman caries sebelumnya berhubungan dengan tanggalnya gigi lebih awal (López-gómez et al., 2016). Beberapa penelitian menunjukkan pengetahuan berhubungan dengan sikap dan perilaku. Sehingga dalam upaya meningkatkan kesehatan gigi dan mulut anak akan dilakukan peningkatan pengetahuan kepada orangtua dan anak serta pelatihan kepada anak.

Penelitian Pautanen menunjukkan pengetahuan orangtua berhubungan dengan perilaku anak dalam menjaga kesehatan mulut (Poutanen et al., 2006). Partisipasi dari sekolah melalui peningkatan pengetahuan kepada guru juga terbukti berpengaruh terhadap kesehatan mulut anak (Petersen et al., 2015).

\section{KESIMPULAN DAN SARAN}

Kegiatan pengabdian masyarakat yang telah dilaksanakan telah berlangsung dengan baik. Hal ini terlihat dari semangat keterlibatan dan antusiasme peserta dalam mengikuti kegiatan pelatihan sangat tinggi. Hal ini juga didukung dengan kehadiran anak yang mencapai $100 \%$ dan orang tua mencapai lebih dari 50\%. Selain itu juga didukung dengan adanya peningkatan pengetahuan yang signifikan segera setelah dilakukan penyuluhan.

Rekomendasi untuk kegiatan pengabdian kepada masyarakat selanjutnya berdasarkan refleksi yang dilakukan tim. Refleksi setelah dilaksanakan kegiatan pengabdian masyarakat ini antara lain: 
1. Penentuan waktu pertemuan dengan orangtua menyesuaikan kegiatan yang dirancang Sekolah. Sedapat mungkin kegiatan bergabung dengan kegiatan sekolah, sehingga orangtua tidak perlu menjadwalkan tersendiri. Dengan demikian, waktu menjadi efisien bagi orangtua dan semakin banyak orangtua yang dapat terlibat dalam kegiatan
2. Pengetahuan orangtua semakin lama skornya menurun, sehingga diperlukan kegiatan yang berkelanjutan untuk mendorong orangtua selalu mengingat pengetahuan yang didapatkan dan diterapkan dalam kehidupan sehari-hari.

\section{DAFTAR PUSTAKA}

Astill, R. G. et al. (2012) 'Sleep, Cognition, and Behavioral Problems in School-Age Children : A Century of Research Meta-Analyzed', Psycological buletin, 138(6), pp. 1109-1138.

Daniels, E. et al. (2012) 'Assessment, management, and prevention of childhood temper tantrums', Journal of the American Academy of Nurse Practitioners, pp. 1-5. doi: 10.1111/j.1745-7599.2012.00755.x.

Fletcher, F. E. et al. (2016) 'The Association Between Anxiety Symptoms and Sleep in SchoolAged Children : A Combined Insight From the Children's Sleep Habits Questionnaire and Actigraphy The Association Between Anxiety Symptoms and Sleep in School-Aged Children : A Combined Insight', Behavioral sleep medicine, 2002(June), pp. 1-16. doi: 10.1080/15402002.2016.1180522.

Gruber, R. et al. (2016) 'School-based sleep education program improves sleep and academic performance of school-age children', Sleep Medicine. Elsevier B.V. doi: 10.1016/j. sleep.2016.01.012.

Hochadel, J. et al. (2013) 'Prevalence of Sleep Problems and Relationship between Sleep Problems and School Refusal Behavior in School-Aged Children in Children's and Parents 'Ratings', Psychopathology, 47, pp. 119-126. doi: 10.1159/000345403.

López-gómez, S. A. et al. (2016) 'Relationship between premature loss of primary teeth with oral hygiene, consumption of soft drinks, dental care, and previous caries experience', 
GEMASSIKA: Jurnal Pengabdian Kepada Masyarakat

Vol. 4 No. 2 November 2020

Nature Publishing Group. Nature Publishing Group, (February), pp. 1-7. doi: 10.1038/ srep21147.

Luangrath, A. (2011) 'Problem behaviour in children An approach for general practice', Australian family physician, 40(9), pp. 678-681.

Petersen, P. E. et al. (2015) 'School-based intervention for improving the oral health of children in southern Thailand', Community Dental Health, 32(June 2014), pp. 44-50. doi: 10.1922/ $\mathrm{CDH}$.

Poutanen, R. et al. (2006) 'Parental influence on children 's oral health-related behavior Parental influence on children 's oral health-related behavior', Acta odontologica Scandinavica, 64(February), pp. 286-292. doi: 10.1080/00016350600714498.

Wahyuningrum, E., Gayatina, A. K. and Yulianti, N. R. (2020) 'Gambaran Pemeriksaan Fisik Anak Usia Sekolah Daerah Perkotaan', Jurnal Ilmiah Keperawatan Stikes Hang Tuah Surabaya, 15(2), pp. 243-256.

Wahyuningrum, E., Rahmat, I. and Hartini, S. (2018) 'Effect of Health Education of Sleep Hygiene on Sleep Problems in Preschoolers', Belitung Nursing Journal, 4(1), pp. 68-75.

Wahyuningrum, E., Yulianti, N. R. and Gayatina, A. K. (2019) 'Gambaran Kebiasaan Tidur Anak Usia Sekolah', Jurnal Keperawatan BSI, 7(2), pp. 1-10. Available at: http://ejurnal. ars.ac.id/index.php/keperawatan/article/view/97/90. 